Info Artikel Diterima Agustus 2017

Disetujui Januari 2018

Dipublikasikan April 2019

\title{
PENGARUH PENGGUNAAN SILASE PAKAN KOMPLIT BERBAHAN \\ ECENG GONDOK TERHADAP KECERNAAN PROTEIN PADA DOMBA
}

\author{
The Effect of Using Complete Feed Silage Made From Water Hyacinth \\ on Protein Digestibility in Sheep
}

\author{
L. Hanun, A. Muktiani, dan L. K. Nuswantara \\ Fakultas Peternakan dan Pertanian Universitas Diponegoro \\ Jl. Prof. H. Soedarto, SH, Tembalang, Semarang 50275 \\ E-mail: anismuktiani@gmail.com
}

\begin{abstract}
This study aims to determine the effect of fedding a complete ration of silage made from water hyacinth on concentration of ammonia rumen, total protein of rumen fluid and protein digestibility. Fifteen rams with average body weight of $19 \pm 3.98 \mathrm{~kg}$ used on this research. The experiment was arranged in $3 \times 5$ randomized completed design. There treatment were $\mathrm{T} 1=$ concentrate and elephant grass, T2= complete feed silage contained water hyacinth without $L$. plantarum starter addition, and $\mathrm{T} 3=$ complete ration silage contained water hyacinth added with L. plantarum. Ration was formulated by isoenergy and isoprotein feed (CP 13\%, TDN 65\%). Feed treatment was given for 12 weeks. The results showed that the consentration of ammonia rumen was different $(\mathrm{P}<0,05)$ in among treatments, but total protein of rumen fluid and protein digestibility di were not different $(\mathrm{P}>0,05)$. Concentration of ammonia rumen of $\mathrm{T} 1, \mathrm{~T} 2$ and $\mathrm{T} 3$ as follows: 2,53, 2,04, 1,80 mM. Total protein of rumen fluid and protein digestibility ranged by 295,70-381,04 $\mathrm{mg} / \mathrm{g}$ and 75,00-77,29\%. The conclusions of this study were the provision of complete feeding silage either without or with the addition of L. plantarum starter to produce the same digestible protein as conventional ration (concentrate and elephant grass).
\end{abstract}

Keywords : silage, water hyacinth, protein, digestibility, sheep.

\begin{abstract}
ABSTRAK
Penelitian ini bertujuan untuk mengetahui pengaruh silase pakan komplit berbahan eceng gondok terhadap amonia rumen, produksi protein total rumen dan kecernaan protein pada domba. Lima belas ekor domba jantan dengan berat badan rata-rata $19 \pm 3,98 \mathrm{~kg}$ sebagai hewan uji. Rancangan percobaan yang digunakan adalah rancangan acak lengkap 3x5. Ransum perlakuan yang diterapkan berupa: $\mathrm{T} 1=$ konsentrat dan rumput gajah, $\mathrm{T} 2=$ silase ransum komplit eceng gondok tanpa penambahan strater L. plantarum, T3= silase ransum komplit berbahan eceng gondok dengan penambahan starter $L$. plantarum. Pakan perlakuan disusun isoenergi dan isoprotein (PK 13\% dan TDN 65\%). Hasil penelitian menunjukkan
\end{abstract}


bahwa amonia rumen berbeda nyata $(\mathrm{p}<0,05)$ antar perlakuan, namun produksi protein total cairan rumen dan kecernaan protein tidak berbeda nyata ( $p>0,05)$. Konsentrasi amonia rumen masing-masing perlakuan T1, T2 dan T3: 2,53, 2,04, $1,80 \mathrm{mM}$, sedangkan produksi protein total cairan rumen dan kecernaan protein masing-masing berkisar antara 295,70-381,04 mg/g dan 75,00-77,29\%. Kesimpulan penelitian ini adalah pemberian silase pakan komplit baik tanpa atau dengan penambahan starter L. plantarum menghasilkan protein tercerna yang sama dengan ransum konvensional (konsentrat dan rumput gajah).

Kata kunci: silase, eceng gondok, protein, kecernaan, domba.

\section{PENDAHULUAN}

Ternak domba relatif mudah pemeliharaannya dan penyebarannya hampir di seluruh wilayah Indonesia. Ternak ruminansia kecil ini juga memiliki kelebihan yaitu mudah dikembangbiakkan dan cepat pertumbuhannya sehingga sangat menguntungkan peternak. Kebutuhan masyarakat akan daging domba terus meningkat dari tahun ke tahun. Kebutuhan tersebut disediakan oleh peternakan rakyat dengan skala usaha kecil dan sistem pemeliharaannya masih bersifat tradisional, dimana manajemen pemberian pakan umumnya tidak memperhatikan kesesuaian dengan kebutuhan ternak. Hal ini diperparah oleh ketersediaan pakan yang tidak kontinyu sepanjang tahun. Pada saat musim kemarau ketersediaan hijauan sangat terbatas, sehingga perlu pakan alternatif lain yang tersedia sepanjang tahun, diantaranya eceng gondok.

Ditinjau dari kandungan nutriennya, eceng gondok mempunyai kualitas yang baik sebagai sumber pengganti pakan hijauan. Eceng gondok segar mempunyai kadar air (KA) sebesar 91,88\%, dan dalam 100\% bahan kering (BK) mempunyai 24,68\% abu, protein kasar (PK) 24,68\%, serat kasar (SK) 16,90\%, lemak kasar (LK) 1,31\% dan 50.00\% bahan ekstrak tanpa nitrogen (Muktiani, 2013).

Sebagai pakan ternak, eceng gondok mempunyai kekurangan yaitu pada kadar air yang tinggi sehingga tidak dapat disimpan dalam waktu yang lama. Oleh karena itu perlu dilakukan pengawetan pada eceng gondok dibuat menjadi silase. Perlu dilakukan penambahan bahan-bahan pakan yang berfungsi sebagai penyerap air pada pembuatan silase eceng gondok sehingga mencapai KA yang ideal, dan menjadi silase pakan komplit. Proses pembuatan silase pakan komplit dapat dipercepat dengan menambahkan starter bakteri asam laktat misalnya dengan pemberian starter L. plantarum. Starter L. Plantarum merupakan bakteri asam laktat yang besifat homofermentatif (hanya membentuk asam laktat dari gula), jika asam laktat semakin cepat terbentuk maka $\mathrm{pH}$ silase akan cepat turun, sehingga silase akan menjadi lebih awet dan tahan lama.

Sumber protein ternak ruminansia berasal dari protein pakan dan protein mikroba rumen. Protein mikroba mempunyai kualitas yang baik, sehingga kondisi rumen yang mendukung pertumbuhan mikroba rumen dapat dijadikan tolok ukur kualitas pakan yang diberikan. Mikroba rumen membutuhkan amonia $\left(\mathrm{NH}_{3}\right)$ sebagai sumber $\mathrm{N}$ dan membutuhkan VFA sebagai sumber energi dan kerangka karbon untuk sintesis protein tubuhnya. Protein pakan yang berkualitas baik 
dibutuhkan untuk memenuhi hal tersebut. Protein pakan didalam rumen akan mengalami proteolisis oleh enzim mikroba rumen menjadi oligopeptida dan asam amino, selanjutnya keduanya akan mengalami deaminasi dan menghasilkan asam keto- $\alpha$, VFA, dan $\mathrm{NH}_{3}$. Kadar $\mathrm{NH}_{3}$ dalam rumen merupakan petunjuk antara proses degradasi dan sintesis protein oleh mikroba di dalam rumen. (McDonald et $a l ., 2002)$. Protein yang lolos dari degradasi rumen berkisar 20-80\%, tergantung kelarutannya dalam cairan rumen. Protein yang lolos dari rumen jumlahnya bervariasi dan tidak semua protein tersebut dapat dirombak oleh mikroba rumen menjadi amonia (Sutardi, 1979). Protein yang lolos degradasi rumen dan protein mikroba rumen selanjutnya disebut protein total rumen, keduanya akan menuju ke saluran pencernaan pasca rumen dan mengalami pencernaan secara enzimatik. Kecernaan protein menunjukkan jumlah protein yang diserap oleh usus dan dimetabolisasi oleh tubuh.

Penelitian ini bertujuan untuk mengetahui penggunaan starter L. plantarum pada proses pembuatan silase pakan komplit berbahan eceng gondok terhadap amonia, protein total cairan rumen dan kecernaan protein pada domba. Manfaat penelitian ini diharapkan dapat memberikan informasi mengenai pakan alternatif berupa silase pakan komplit berbahan eceng gondok yang menggunakan starter $L$. plantarum berdasarkan ketersediaan protein bagi ternak.

\section{BAHAN DAN METODE}

Penelitian dilaksanakan di Laboratorium Ilmu Nutrisi dan Pakan Fakultas Peternakan dan Pertanian Universitas Diponegoro, Semarang. Sebanyak 15 ekor domba lokal jantan dengan umur 12 bulan dengan bobot badan rata-rata 19 $\pm 3,98$ kg. Ditempatkan pada kandang individu yang dilengkapi dengan palung pakan dan masing-masing diberi pakan percobaan berupa silase ransum komplit berbahan dasar eceng gondok. Percobaan disusun berdasarkan rancangan acak lengkap (RAL) dengan tiga perlakuan dan lima ulangan. Perlakuan yang akan diujikan adalah sebagai berikut: konsentrat dan rumput gajah (T1), silase pakan komplit berbahan eceng gondok tanpa starter L. Plantarum (T2), dan silase pakan komplit berbahan eceng gondok dengan penambahan starter L. Plantarum (T3).

Pembuatan pakan berupa silase ransum komplit dilakukan melalui proses pelayuan eceng gondok selama 24 jam, dilanjutkan dengan pencacahan dan penimbangan. Eceng gondok kemudian ditambahkan kedalam campuran pakan komplit sesuai dengan formulasi ransum. Penambahan molasses dan starter $L$. plantaraum pada ransum percobaan sebelum dilakukan fermentasi. Bahan pakan yang sudah tercampur merata difermentasi dalam drum plastik setelah terlebih dahuhu dipadatkan agar tidak terdapat udara dalam silo. Fermentasi dilkukan selama 2 minggu. Formulasi dan kandungan ransum dapat dililhat pada Tabel 1.

Tahap pelaksanaan dilakukan selama 12 minggu yang terdiri dari 2 minggu adaptasi ransum dan 10 minggu pengambilan data retensi nitrogen, konsumsi protein dan kecernaan protein. Pada tahap adaptasi domba diberi pakan berupa rumput saja kemudian semakin hari dikurangi proporsinya dengan ditambah pakan perlakuan. Pemberian pakan dalam BK dihitung 5\% dari bobot badan domba. Pakan perlakuan dan air minum diberikan secara ad libitum. Pemberian rumput gajah pada perlakuan kontrol diberikan minimal selang satu 
jam setelah pemberian konsentrat. Penimbangan sisa pakan perlakuan dilakukan keesokan harinya sebelum memberikan pakan perlakuan pada pagi hari.

Tabel 1. Formulasi dan kandungan Nutrisi Ransum Perlakuan

\begin{tabular}{lccc}
\hline \multirow{2}{*}{ Kadar Nutrien } & \multicolumn{3}{c}{ Perlakuan } \\
\cline { 2 - 4 } & T1 & T2 & T3 \\
\hline \multirow{2}{*}{ Bahan Kering } & 35,68 & 30,15 & 30,66 \\
Protein Kasar & 12,97 & 13,31 & 13,53 \\
Serat Kasar & 25,14 & 24,74 & 25,15 \\
TDN & 64,82 & 65,12 & 66,22 \\
Lemak Kasar & 6,11 & 5,51 & 5,60 \\
Abu & 11,51 & 11,21 & 11,40 \\
BETN & 44,27 & 45,27 & 44,32 \\
\hline
\end{tabular}

Keterangan: TDN=total digestible nutrient, $\mathrm{BETN}=$ bahan ekstrak tanpa nitrogen.

Parameter yang diukur pada penelitian ini adalah kecernaan protein, amonia dan protein total. Pengukuran kecernaan protein dilakukan dengan metode total koleksi. Feses dan urine dikoleksi setiap hari dan disemprot menggunakan $\mathrm{H}_{2} \mathrm{SO}_{4} 3 \%$ setiap 3 jam sekali. Koleksi feses dilakukan selama satu minggu berturut-turut, berat basah feses dicatat, kemudian feses dikeringkan di bawah sinar matahari, dihomogenisasikan dan diambil sampel 10\%. Feses dibersihkan dari bulu dan kotoran lain selanjutnya dianalisis kadar bahan kering dan kadar protein kasarnya. Kecernaan protein diukur sebagai selisih antara protein yang dikonsumsi dengan protein yang dikeluarkan melalui feses (Prayuwidayati dan Widodo, 2007).

$$
\text { Kecernaan Protein }=\frac{\text { Protein yang dikonsumsi }(\mathrm{gBK})-\text { Protein feses }(\mathrm{gBK})}{\text { Protein yang dikonsumsi }(\mathrm{gBK})} \times 100 \%
$$

Pengukuran amonia dan protein total cairan rumen dilakukan melalui pengambilan sampel cairan rumen setelah 3 jam pemberian pakan selanjutnya dianalisis amonia dan protein total caiaran rumen. Perhitungan konsentrasi $\mathrm{NH}_{3}$ menggunakan rumus :

$\mathrm{NH}_{3}(\mathrm{mM})=\left(\mathrm{ml} \mathrm{H}_{2} \mathrm{SO}_{4} \times\right.$ normalitas $\left.\mathrm{H}_{2} \mathrm{SO}_{4}\right) \times 1000$.

\section{HASIL DAN PEMBAHASAN}

Hasil pengaruh penggunaan silase pakan komplit berbahan eceng gondok terhadap amonia, produksi total cairan rumen dan kecernaan protein secara lengkap tercantum pada Tabel 2 dan 3.

\section{$\mathrm{NH}_{3}$ Rumen}

Penggunaan starter L. Plantarum pada proses pembuatan silase pakan komplit berbahan eceng gondok berpengaruh nyata terhadap konsentrasi $\mathrm{NH}_{3}$ rumen. Kadar $\mathrm{NH}_{3}$ rumen merupakan sumber nitrogen yang utama untuk sintesis 
protein mikrobia rumen. Perlakuan yang menggunakan konsentrat dan rumput gajah (T1) menghasilkan kadar NH3 yang lebih tinggi dibandingkan dengan ransum silase pakan komplit berbahan eceng gondok (T2 dan T3). Menurut McDonald et al. (2002) bahwa konsentrasi $\mathrm{NH}_{3}$ yang tinggi dapat menunjukkan proses degradasi protein pakan lebih cepat dibanding proses pembentukan protein mikroba, sehingga amonia yang dihasilkan terakumulasi dalam rumen. Sebaliknya pada perlakuan pemberian silase pakan komplit pemanfaatan NH3 untuk sintesis protein mikroba lebih tinggi.

Tabel 2. Pengaruh penggunaan silase pakan komplit berbahan enceng gondok terhadap kadar VFA, $\mathrm{NH}_{3}$ dan protein total cairan rumen pada domba.

\begin{tabular}{lrrr}
\hline \hline \multirow{2}{*}{ Parameter } & \multicolumn{3}{c}{ Perlakuan } \\
\cline { 2 - 4 } & \multicolumn{1}{c}{$\mathrm{T} 1$} & \multicolumn{1}{c}{$\mathrm{T} 2$} & \multicolumn{1}{c}{$\mathrm{T} 3$} \\
\hline VFA Total $(\mathrm{mM})$ & 54,57 & 49,60 & 51,44 \\
$\mathrm{NH}_{3}$ Rumen $(\mathrm{mM})$ & $2,53 \pm 0,32^{\mathrm{a}}$ & $2,04 \pm 0,24^{\mathrm{b}}$ & $1,80 \pm 0,25^{\mathrm{b}}$ \\
Protein Total $(\mathrm{mg} / \mathrm{g})$ & $295,70 \pm 79,27$ & $363,77 \pm$ & $381,04 \pm$ \\
& & 179,69 & 171,79 \\
\hline
\end{tabular}

a, b superskrip dengan huruf kecil yang berbeda pada baris yang sama menunjukkan perbedaan yang nyata $(\mathrm{p}<0,05)$.

Konsentrasi $\mathrm{NH}_{3}$ pada penelitian ini berkisar antara 1,80-2,53 mM. Hal ini menunjukkan bahwa pakan perlakuan mempunyai kandungan protein yang sukar dicerna atau lolos degradasi di dalam rumen. Kisaran amonia rumen tersebut belum mendukung aktifitas mikroba rumen. Sesuai dengan pendapat Stern dan Hoover (1979) konsentrasi $\mathrm{NH}_{3}$ yang dibutuhkan untuk menunjang pertumbuhan mikrobia rumen yang maksimal berkisar antara 2,94-17,06 mM. Pendapat lain menyatakan bahwa jika pakan defisien protein atau tinggi kandungan protein yang lolos degradasi, maka konsentrasi $\mathrm{NH}_{3}$ rumen akan rendah (lebih rendah dari 50 $\mathrm{mg} / 1$ atau 3,57 Mm) dan pertumbuhan organisme rumen akan lambat (Satter dan Slyter, 1974). Sebaliknya, jika degradasi protein lebih cepat dari pada sintesis protein mikroba maka $\mathrm{NH}_{3}$ akan terakumulasi dan melebihi konsentrasi optimumnya. Astuti et al. (2007) menyatakan bahwa konsentrasi $\mathrm{NH}_{3}$ dalam rumen dipengaruhi oleh tingkat produksinya yang berkaitan dengan pencernaan protein pakan dan dipengaruhi pula oleh laju penggunaannya oleh mikroba rumen.

\section{Protein Total}

Hasil analisis ragam menunjukkan perlakuan pemberian pakan komplit berbahan eceng gondok tidak berpengaruh nyata terhadap produksi protein total cairan rumen $(\mathrm{P}>0,05)$. Produksi protein total pada penelitian ini berkisar antara 295,70-381,04 mg/g. Hasil ini lebih tinggi dibandingkan dengan hasil penelitian Ani (2014) yang meneliti proteksi protein menggunakan tanin dan saponin yaitu berkisar antara 114,7-189,18 mg/g. Faktor-faktor yang mempengaruhi produksi protein total yaitu produksi VFA, amonia, kerangka karbon, ketersediaan energi, suplai mineral, tingkat konsumsi, dan laju aliran partikel pakan. Hasil penelitian ini baik produksi amonia $(1,21-2,50 \mathrm{mM})$ maupun produksi VFA $(49,60-54,57$ $\mathrm{mM}$ ) sangat rendah, sehingga produksi protein mikroba yang dihasilkan diduga 
juga rendah. Dengan demikian produksi protein total tersebut lebih banyak disumbang dari protein yang lolos degradasi rumen. Dan terlihat dari data penelitian bahwa silase pakan komplit mempunyai kandungan protein lolos degradasi rumen lebih tinggi disbanding ransum konvensional. Menurut Orskov (1992) sifat fisik bahan pakan merupakan faktor utama yang menentukan karakteristik degradasi bahan tersebut dalam rumen. Protein total rumen diperoleh dari protein mikroba dan protein pakan yang lolos dari degradasi. Protein yang lolos dari degradasi rumen berkisar $20-80 \%$, tergantung kelarutannya dalam cairan rumen. Protein yang lolos dari rumen jumlahnya bervariasi dan tidak semua protein tersebut dapat dirombak oleh mikroba rumen menjadi amonia. Hal ini terjadi karena mikroba rumen tidak mampu mengangkut asam amino kedalam tubuhnya, maka mikroba tersebut lebih suka untuk merombak asam amino menjadi amonia (Sutardi, 1979).

\section{Kecernaan Protein}

Penggunaan Starter L. Plantarum pada silase pakan komplit berbahan eceng gondok pada penelitian ini tidak berpengaruh nyata terhadap kecernaan protein $(\mathrm{P}>0,05)$. Kecernaan protein pada perlakuan $\mathrm{T} 1, \mathrm{~T} 2, \mathrm{~T} 3$ adalah sebesar 75,00-77,29\%. Hasil penelitian ini relatif sama dengan hasil penelitian Ndaru et al. (2014) bahwa kecernaan protein pada suplementasi berbagai level daun ketela pohon terhadap produktifitas domba ekor gemuk yang diberi pakan basal jerami jagung yaitu berkisar antara 70,73-78,61\%.

Kecernaan protein yang tidak berbeda pada penelitian ini diduga karena kandungan protein pakan yang relatif sama, sehingga akan menghasilkan pertumbuhan bakteri rumen yang tidak berbeda. Hal ini sesuai dengan pendapat Prihatini et al. (2011) bahwa faktor yang berpengaruh pada kecernaan adalah ketersediaan nutrien sebagai makanan untuk pertumbuhan mikroba. Meskipun potensi pakan untuk dicerna tinggi tetapi apabila lingkungan rumen tidak mendukung untuk aktivitas fermentasi mikrobia rumen maka kecernaan akan menjadi rendah.

Tabel 3. Kecernaan Protein Pakan.

\begin{tabular}{|c|c|c|c|}
\hline \multirow{2}{*}{ Parameter } & \multicolumn{3}{|c|}{ Perlakuan } \\
\hline & $\mathrm{T} 1$ & $\mathrm{~T} 2$ & T3 \\
\hline Konsumsi Protein (g/hari) & $87,97 \pm 14,41$ & $\begin{array}{r}108,00 \pm \\
12,50\end{array}$ & $94,17 \pm 13,58$ \\
\hline Ekskresi $\mathrm{N}$ via Feses (g/hari) & $3,25 \pm 0,09^{b}$ & $\begin{array}{r}4,33 \pm \\
0,05^{\mathrm{a}}\end{array}$ & $3,50 \pm 0,09^{a}$ \\
\hline Kecernaan Protein $(\%)$ & $77,29 \pm 4,64$ & $75,00 \pm 1,03$ & $77,07 \pm 4,92$ \\
\hline
\end{tabular}

Menurut Arora (1995) daya cerna suatu bahan pakan dipengaruhi oleh laju pakan dalam saluran pencernaan, bentuk fisik pakan dan komposisi pakan. Dalam hal ini kecernaan perlakuan T1, T2 dan T3 tidak berbeda nyata diduga karena laju pakan dalam saluran pencernaan yang tidak berbeda. Komposisi pakan yang 
relatif sama yaitu terdiri dari hijauan dan konsentrat meskipun pada perlakuan T2 dan T3 kemudian dibuat silase menyebabkan laju pakan yang sama di dalam saluran pencernaan. Menurut Prasetiyono et al, (2007), kecernaan pakan yang tinggi mengindikasi bahwa laju pengosongon isi rumen berlangsung cepat. Soebarinoto et al. (1991) dan Rianto et al. (2006) menyatakan bahwa tingkat konsumsi juga mempengaruhi kecernaan, konsumsi pakan yang tinggi menyebabkan laju digesta didalam saluran pencernaan semakin tinggi, sehingga waktu yang tersedia bagi enzim untuk memecah nutrien menjadi terbatas dan pada akhirnya kecernaan pakan menjadi menurun. Perlakuan pada penelitian ini menghasilkan tingkat konsumsi yang tidak berbeda, dengan demikian menghasilkan tingkat kecernaan yang tidak berbeda pula. Menurut Tillman et al. (1998) peningkatan konsumsi dapat menurunkan kecernaan, terkait dengan laju alir pakan dalam saluran pencernaan yang semakin cepat, akibatnya lama waktu tinggal digesta dalam rumen berkurang sehingga proses pencernaan tidak optmal.

\section{KESIMPULAN}

Kesimpulan penelitian ini adalah pemberian silase pakan komplit baik tanpa atau dengan penambahan starter $L$. plantarum menghasilkan protein tercerna yang sama dengan ransum konvensional (konsentrat dan rumput gajah).

\section{DAFTAR PUSTAKA}

Ani, A. S. 2014. Proteksi Protein Menggunakan Tanin dan Saponin untuk Meningkatkan Fermentabilitas Ruminal. Fakultas Peternakan dan Pertanian. Universitas Diponegoro. Semarang. (Tesis Magister).

Arora, S.P. 1995. Pencernaan Mikroba dan Ruminansia. Gadjah Mada University Press, Yogyakarta. (Diterjemahkan oleh R. Murwani)

Astuti, W. D., R. Ridwan dan B. Tappa. 2007. Penggunaan Probiotik dan Kromium Organik terhadap Kondisi Lingkungan Rumen In Vitro. JITV 12 (4): 262-267.

McDonald, P., R.A. Edward, J.F.D. Greenhalgh dan C.A. Morgan. 2002. Animal Nutrition. Longman Scientific and Technical Copublished, New York.

Muktiani, A. 2013. Peningkatan Kualitas Pakan Ternak Berbahan Eceng Gondok. Prosiding. Workshop Penyelamatan Ekosistem Danau Rawa Pening, Semarang. 13 Juni 2013. Kementerian Lingkungan Hidup bekerjasama dengan Universitas Diponegoro. 65-72.

Ndaru P. H., Kusmartono dan S. Chuzaemi. 2014. Pengaruh Suplementasi Berbagai Level Daun Ketela Pohon (manihot utilissima. Pohl) terhadap Produktivitas Domba Ekor Gemuk Yang Diberi Pakan Basal Jerami Jagung (zea mays). Jurnal Ilmu-Ilmu Peternakan 24 (1):9-25. 
Orskov, E. R. 1992. Protein Nutrition in Ruminant. Academic Press Inc, London.

Prasetiyono, B.W.H.E., Suryahadi, T. Toharmat dan R. Syarief. 2007. Strategi Suplementasi Protein Ransum Sapi Potong Berbasis Jerami Dan Dedak Padi. Media Peternakan. 30 : 207-217.

Prayuwidayati, M.M. dan Y. Widodo. 2007. Penggunaan Bagas Tebu Teramoniasi Dan Terfermentasi Dalam Ransum Ternak Domba. Majalah Ilmu Peternakan. 10 : 1-14.

Prihatini, I., Soebarinoto., S. Chuzaemi dan M. Winugroho. 2011. Karakteristik Nutrisi Dan Degradasi Jerami Padi Fermentasi Oleh Inokulum Lignolitik TliD dan BopR. Animal Production. 11 (1): 1-7.

Rianto, E., E. Haryono dan C.M. Lestari. 2006. Produktivitas Domba Ekor Tipis Jantan Yang Diberi Pollard Dengan Aras Berbeda. Prosiding Seminar Nasional Teknologi Peternakan dan Veteriner. Puslitbang Peternakan, Bogor. Hal: 431-439.

Soebarinoto., S. Chuzaemi dan Marshudi. 1991. Ilmu Gizi Ruminansia. Jurusan Nutrisi dan Makanan Ternak Universitas Brawijaya, Malang.

Satter, L.D. dan L.L. Slyter. 1974. Effect of Amonia Concentration on Ruminal Microbial Protein Production In Vitr. Brit. J. Nutr. Anim. Sci. 32 :199203.

Stern, M.D. dan W.H. Hoover. 1979. Methods for Determination and Factors Affecting Rumen Microbial Synthesis. J. Anim Sci. 49 : 1590-1603.

Sutardi, T. 1979. Ketahanan Protein Bahan Makanan Terhadap Degradasi Oleh Mikroba Rumen Dan Manfaatnya Bagi Peningkatan Produktivitas Ternak. Pros. Seminar Penelitian dan Penunjang Peternakan. LPP-Deptan, Bogor. 2: 91-103.

Tillman, A. D., H. Hartadi., S. Reksohadiprodjo, S. Prawirokusumo dan S. Lebdosoekojo. 1998. Ilmu Makanan Ternak Dasar. Edisi ke-5. Gadjah Mada University Press, Yogyakarta. 